\title{
The Impact of Resistance Enhancement in Tomato Plants on Tetranychus urticae Life history traits
}

\author{
Ahmed, M. M. \\ "Zoology and Agric. Nematology Dept., Faculty of Agriculture, Cairo Univ., Giza, Egypt, \\ mahmoudmonir@agr.cu.edu.eg
}

\begin{abstract}
The duration of developmental stages and life table parameters of the two spotted-spider mite; Tetranychus urticae Koch were carried out at the laboratory on $27 \pm 3^{\circ} \mathrm{C}$ and $65 \pm 5 \%$ R.H. on leaves of two tomato hybrids; Supper-gekal and Salymia treated with improve resistance compounds, (Potassium humates, Potassium silicates, Salicylic acid and Methyl jasmonate) and untreated plants as control. These compounds used in enhancement resistance in tomato plants are significantly related to oviposition and developmental rates of T. urticae and playing an important role in the direct defence to the mite. The adult longevity and fecundity of T. urticae, female decreased when reared on leaves of two treated tomato hybrids than leaves of untreated. The net reproductive rate $\left(\mathrm{R}_{\mathrm{o}}\right)$ of $T$. urticae, decreasing when rearing on leaves of two the tomato hybrids treated, averaged (22.96, 24.87, 27.20, $23.45 \& 19.10,13.38,19.65$ and 18.45 females/female /day respectively, compared with rearing on leaves of untreated tomato hybrids (control) averaging 48.17 and 37.72 females/female /day respectively. Also, the intrinsic rate of natural increase $\left(\mathrm{r}_{\mathrm{m}}\right)$ showed similar trend as the net reproductive rate $\left(R_{\circ}\right)$. The thickness $\mu \mathrm{m}$ of the epidermis, parenchyma cells and components in sponge and palisade parenchyma cells (cellular wall, chloroplasts, intercellular space and sg-numerous starch grains) where affected by these compounds used in resistance enhancement in tomato plants, investigated them with transmission electron micrograph.
\end{abstract}

Key words: Biology, Life tables parameters, Tetranychus urticae and Tomato resistance.

\section{INTRODUCTION}

Induced resistance could be exploited as an important tool for the pest management to minimize the amounts of Acaricides used for mite control. Host plant resistance to mites, particularly, induced resistance, can also be manipulated with the use of chemical elicitors of secondary metabolites, which confer resistance to mites.

Differences in mite fitness are influenced by plant morphological and chemical characteristics, as well as plant defense mechanisms. These characteristics and mechanisms depend on plant genotype, pest species, and the interactions between both (Dent, 2000 and Vásquez, et al., 2018). Plant hormones play a critical role in regulating plant growth, development, and defense mechanisms (Verhage, et al., 2010). Most of the plant defense responses against insects and mites are activated by signal transduction pathways mediated by JA, SA, and ethylene (Shivaji, et al., 2010 and Afifi, et al., 2015). Salicylic acid, Jasmonic acid, potassium humates and potassium silicate are involved in plant defense against the red spider mite, T. urticae, JA is the most important phytohormone linked to plant defense against herbivores and activates the expression of both direct and indirect defenses (Shivaji, et al., 2010; War, et al., 2011 and Afifi, et al., 2015).

The life table parameters, especially intrinsic rate of increase $\left(\mathrm{r}_{\mathrm{m}}\right)$, have been used as indicators of pest population performance to assess the level of plant resistance to herbivorous pests (Ali, et al., 2013 and Golizadeh, et al., 2016).
The objective of this study is to investigate effect resistance enhancement in tomato plants on the developmental stages and life table parameters of $T$. urticae.

\section{MATERIALS AND METHODS}

The experiment (1) was conducted in Acarology Greenhouse, Faculty of Agriculture, Cairo University, Egypt, during season 2017. The experimental area was divided into four treatments (Potassium humates, Potassium silicates, Salicylic acid and Methyl jasmonate) in addition to the control with each tomato hybrid (Supper-gekal and Salymia (65010)) according to complete randomized block design including three replicates for each treatment.

Tomato plants received all normal agricultural processes without any pesticides application. The application of spray was started after two weak of cultivation. Check treatment was sprayed with water only. Spraying plants was weekly for three months of seedlings cultivation. The compounds produced company with their concentration used in this study were mentioned in (Afifi, et al., 2015).

The experiment (2): The duration of developmental stages, life history, and fecundity of $T$. urticae were carried out on leaves of two the tomato hybrids Supper-gekal and Salymia (65010) under controlled conditions with a temperature of $27 \pm 3{ }^{\circ} \mathrm{C}$ and RH of $65 \pm 5 \%$ in the Acarology Laboratory, Faculty of Agriculture, Cairo University.

Tomato leaf discs ( $2 \mathrm{~cm}$ diameter) were placed on cotton bed in petri dish $(60 \mathrm{Mm}$ X $15 \mathrm{Mm})$ with under 
surface upward. The cotton bed was soaked with water twice daily. Ten T. urticae adult females collected from the laboratory stock cultures were transferred to each disc for laying eggs. For solitary rearing, newly deposited eggs of the same age were transferred singly, each to a leaf disc. Every dish contained 30 discs. Dishes with discs were kept at $27 \pm 3^{\circ} \mathrm{C}$ and $65 \pm 5 \%$ R.H. Discs were examined twice daily, and all biological aspects were recorded until the death of mite individuals.

Life tables of T. urticae were constructed from the life history and fecundity data. The actual death occurred in the egg and immature stages were taken into account when the female survival rate. Life tables parameters were constructed using the survival data of a specific age class $\left(L_{x}\right)$ and the female offspring produced per female in each age class $\left(\mathrm{m}_{\mathrm{x}}\right)$ according to (Birch, 1948) using the basic computer program of (Abou-Setta, et al., 1986).

\section{Histological characteristics of tomato leaves}

Leaf samples of two tomato hybrids (treatments and control) imaged spongy parenchyma cells and palisade parenchyma cells behind the midrib of tomato leaves using the Transmission Electron Microscopy in TEM lab FA-CURP, Faculty of Agriculture, Cairo University -Research Park (CURP) using TEM technique according to (Bozzola and Russell 1999). Slice tissue samples into $\sim 1 \mathrm{~mm}$ slices. Slice tissue was processed for TEM by fixation in glutaraldehyde and osmium tetroxide, dehydrated in alcohol and embedded in an epoxy resin. Microtome sections prepared at approximately 500-1000 $\mu \mathrm{m}$ thickness with a Leica Ultracut UCT ultramicrotome. Thin sections were stained with tolodin blue $(1 \mathrm{X})$ then sections were examined by camera Lica ICC50 HD. Ultra-thin sections prepared at approximately 75-90 $\mu \mathrm{m}$ thickness and were stained with uranyl acetate and lead citrate, then examined by transmission electron microscope JEOL (JEM-1400 TEM) at the candidate magnification.

Leaf samples of two tomato hybrids were submerged in ethylene glycol for 6 days then fixed in FAA (formalin-acetic acid-alcohol) and processed by usual techniques of paraffin infiltration. Semiultrathin sections $(1 \mu \mathrm{m})$ for light microscope (LM) were made using a microtome, then stained with methylene blue. Images were captured by CCD camera model AMT, optronics camera with 1632 x 1632-pixel formate as side mount configuration. This camera uses a 1394 firewire board for acquisition. Selected light microscopy images were transferred electronically from the microscope to the computer using the Photo Express software.

\section{RESULTS AND DISCUSSION}

\section{Duration of developmental stages}

The compounds (Potassium humates, Potassium silicates, Salicylic acid and Methyl jasmonate) used in resistance enhancement in tomato plants affected the duration of T. urticae developmental stages, Table (1). The duration of total immature stages and life cycle of $T$. urticae, female increased when rearing on leaves of two tomato hybrids (Supper-gekal and Salymia 65010) treated with potassium humates, potassium silicates, salicylic acid and methyl jasmonate compared with rearing on leaves of untreated tomato hybrid (control). Male showed similar trend as female but with slightly shorter periods. Also, the duration of $T$. urticae developmental stages was shorter when rearing on leaves of Supper-gekal than rearing on leaves of Salymia tomato hybrid. This may be due to the morphological and histological differences of tomato hybrid leaves and its chemical contents from secondary compounds.

\section{Adult longevity and fecundity}

On the contrary, the adult longevity of T. urticae, female decreasing when rearing on leaves of two tomato hybrids (Supper-gekal and Salymia) treated with potassium humates, potassium silicates, salicylic acid and methyl jasmonate averaged $(13.00,13.55$, $13.90,13.37 \& 13.36,11.75,11.55$ and 13.63 days respectively, compered with rearing on leaves of untreated tomato hybrid (control) averaged 15.26 and 14.13 respectively. The number of deposited eggs per female and daily rate of $T$. urticae averaged $30.27 \&$ $3.31 ; 36.05 \& 3.73 ; 37.28 \& 3.68 ; 35.79 \& 3.62$ and $25.14 \& 2.83 ; 18.48 \& 2.53 ; 25.91 \& 3.52 \& 18.16 \&$ 2.94 eggs when reared on leaves of the two treated tomato hybrids respectively, but it averaged 60.74 \& 4.92 and $47.65 \& 4.50$ eggs respectively, when reared on leaves of the two untreated tomato hybrids.

\section{Life table parameters of $T$. urticae}

The compounds (Potassium humates, Potassium silicates, Salicylic acid and Methyl jasmonate) used in resistance enhancement in tomato plants affected the values of life table parameters of $T$. urticae reared on leaves of the two tomato hybrids especially the net reproductive rate $\left(\mathrm{R}_{\mathrm{o}}\right)$ and the intrinsic rate of natural increase $\left(r_{m}\right)$ Table 3.

The net reproductive rate $\left(\mathrm{R}_{\mathrm{o}}\right)$ of $T$. urticae, decreased when rearing on leaves of the two tomato hybrids (Supper-gekal and Salymia) treated with potassium humates, potassium silicates, salicylic acid and methyl jasmonate averaging $(22.96,24.87,27.20$, $23.45 \& 19.10, \quad 13.38, \quad 19.65$ and 18.45 females/female /day respectively, compared with rearing on leaves of untreated tomato hybrid (control) 
Table 1. Duration of developmental stages of Tetranychus urticae on leaves of two tomato hybrid

\begin{tabular}{|c|c|c|c|c|c|c|c|}
\hline \multirow{2}{*}{$\begin{array}{l}\text { Tomato } \\
\text { hybrids }\end{array}$} & \multirow[b]{2}{*}{ Stages } & \multirow[b]{2}{*}{ Sex } & \multicolumn{5}{|c|}{ Duration of developmental stages } \\
\hline & & & $\begin{array}{c}\text { Potassium } \\
\text { humates }\end{array}$ & $\begin{array}{l}\text { Potassium } \\
\text { silicates }\end{array}$ & $\begin{array}{c}\text { Salicylic } \\
\text { acid }\end{array}$ & $\begin{array}{c}\text { Methyl } \\
\text { jasmonate }\end{array}$ & Control \\
\hline \multirow{12}{*}{ Supper-gekal } & \multirow{2}{*}{ Egg } & $\hat{0}$ & $3.86 \pm 0.14$ & $3.56 \pm 0.24$ & $4.00 \pm 0.19$ & $3.50 \pm 0.17$ & $3.83 \pm 0.17$ \\
\hline & & 오 & $4.55 \pm 0.11$ & $4.55 \pm 0.11$ & $4.71 \pm 0.16$ & $4.37 \pm 0.14$ & $4.57 \pm 0.11$ \\
\hline & \multirow{2}{*}{ Larva } & $\hat{0}$ & $1.86 \pm 0.26$ & $1.78 \pm 0.15$ & $2.75 \pm 0.25$ & $1.70 \pm 0.21$ & $1.50 \pm 0.22$ \\
\hline & & 우 & $2.23 \pm 0.16$ & $1.95 \pm 0.15$ & $3.10 \pm 0.15$ & $2.05 \pm 0.16$ & $1.87 \pm 0.13$ \\
\hline & \multirow{2}{*}{ Protonymph } & $0^{\lambda}$ & $1.71 \pm 0.29$ & $1.56 \pm 0.18$ & $1.75 \pm 0.16$ & $1.60 \pm 0.16$ & $1.33 \pm 0.21$ \\
\hline & & P & $1.86 \pm 0.19$ & $1.90 \pm 0.18$ & $1.90 \pm 0.15$ & $1.84 \pm 0.14$ & $1.65 \pm 0.15$ \\
\hline & \multirow{2}{*}{ Deutonymph } & $\hat{0}$ & $1.86 \pm 0.14$ & $1.67 \pm 0.17$ & $2.13 \pm 0.30$ & $1.90 \pm 0.18$ & $1.83 \pm 0.17$ \\
\hline & & 우 & $2.32 \pm 0.12$ & $2.45 \pm 0.11$ & $2.57 \pm 0.11$ & $2.63 \pm 0.11$ & $2.35 \pm 0.12$ \\
\hline & \multirow{2}{*}{$\begin{array}{c}\text { Total } \\
\text { immatures }\end{array}$} & $\hat{0}$ & $5.43 \pm 0.53$ & $5.00 \pm 0.29$ & $6.63 \pm 0.60$ & $5.20 \pm 0.29$ & $4.67 \pm 0.33$ \\
\hline & & 오 & $6.41 \pm 0.24$ & $6.30 \pm 0.27$ & $7.57 \pm 0.25$ & $6.53 \pm 0.22$ & $5.87 \pm 0.27$ \\
\hline & \multirow{2}{*}{ Life cycle } & $\hat{0}$ & $9.29 \pm 0.57$ & $8.56 \pm 0.38$ & $10.63 \pm 0.68$ & $8.70 \pm 0.33$ & $8.50 \pm 0.34$ \\
\hline & & 우 & $10.95 \pm 0.28$ & $10.85 \pm 0.31$ & $12.29 \pm 0.33$ & $10.89 \pm 0.30$ & $10.43 \pm 0.29$ \\
\hline \multirow{12}{*}{$\begin{array}{l}\text { Salymia } \\
(65010)\end{array}$} & \multirow{2}{*}{ Egg } & $0^{2}$ & $4.14 \pm 0.26$ & $4.13 \pm 0.30$ & $3.86 \pm 0.14$ & $3.78 \pm 0.22$ & $4.20 \pm 0.20$ \\
\hline & & 오 & $5.10 \pm 0.17$ & $4.45 \pm 0.17$ & $4.68 \pm 0.15$ & $4.37 \pm 0.14$ & $4.65 \pm 0.10$ \\
\hline & \multirow{2}{*}{ Larva } & 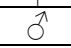 & $2.43 \pm 0.20$ & $2.50 \pm 0.19$ & $2.71 \pm 0.29$ & $2.33 \pm 0.17$ & $2.40 \pm 0.24$ \\
\hline & & 우 & $2.73 \pm 0.12$ & $2.70 \pm 0.15$ & $3.05 \pm 0.14$ & $2.68 \pm 0.17$ & $2.56 \pm 0.11$ \\
\hline & \multirow{2}{*}{ Protonymph } & $\hat{0}$ & $2.14 \pm 0.14$ & $2.13 \pm 0.13$ & $1.86 \pm 0.26$ & $2.11 \pm 0.11$ & $1.60 \pm 0.24$ \\
\hline & & 오 & $2.32 \pm 0.10$ & $2.35 \pm 0.11$ & $2.73 \pm 0.15$ & $2.32 \pm 0.13$ & $1.87 \pm 0.10$ \\
\hline & \multirow{2}{*}{ Deutonymph } & $\frac{T}{0}$ & $2.86 \pm 0.14$ & $2.38 \pm 0.18$ & $2.57 \pm 0.20$ & $2.56 \pm 0.18$ & $2.20 \pm 0.37$ \\
\hline & & 우 & $3.18 \pm 0.14$ & $1.95 \pm 0.14$ & $2.91 \pm 0.11$ & $2.79 \pm 0.14$ & $2.69 \pm 0.10$ \\
\hline & \multirow{2}{*}{$\begin{array}{c}\text { Total } \\
\text { immatures }\end{array}$} & 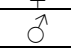 & $7.43 \pm 0.20$ & $7.00 \pm 0.33$ & $7.14 \pm 0.40$ & $7.00 \pm 0.24$ & $6.20 \pm 0.49$ \\
\hline & & 오 & $8.28 \pm 0.19$ & $8.00 \pm 0.21$ & $8.68 \pm 0.27$ & $7.79 \pm 0.27$ & $7.13 \pm 0.14$ \\
\hline & \multirow{2}{*}{ Life cycle } & $\hat{0}$ & $11.57 \pm 0.30$ & $11.13 \pm 0.44$ & $11.00 \pm 0.49$ & $10.78 \pm 0.28$ & $10.40 \pm 0.40$ \\
\hline & & $q$ & $13.32 \pm 0.27$ & $12.45 \pm 0.29$ & $13.36 \pm 0.33$ & $12.16 \pm 0.30$ & $11.78 \pm 0.17$ \\
\hline
\end{tabular}

Table (2): Longevity and fecundity of Tetranychus urticae female on two tomato hybrids at $27 \pm 3^{\circ} \mathrm{C}$

\begin{tabular}{|c|c|c|c|c|c|c|c|}
\hline \multirow[b]{2}{*}{ Treatments } & \multirow[b]{2}{*}{ Tomato hybrid } & \multicolumn{4}{|c|}{ Periods in days } & \multicolumn{2}{|c|}{ Fecundity } \\
\hline & & $\begin{array}{c}\text { Pre- } \\
\text { oviposition }\end{array}$ & Oviposition & $\begin{array}{c}\text { Post } \\
\text { oviposition }\end{array}$ & $\begin{array}{c}\text { Adult } \\
\text { longevity }\end{array}$ & $\begin{array}{l}\text { No. of eggs / } \\
\text { female }\end{array}$ & $\begin{array}{c}\text { Daily } \\
\text { rate }\end{array}$ \\
\hline \multirow{2}{*}{$\begin{array}{l}\text { Potassium } \\
\text { humates }\end{array}$} & Supper-gekal & $1.95 \pm 0.12$ & $9.14 \pm 0.50$ & $1.91 \pm 0.11$ & $13.00 \pm 0.47$ & 30.27 & 3.31 \\
\hline & Salymia (65010) & $2.18 \pm 0.11$ & $9.23 \pm 0.38$ & $1.95 \pm 0.12$ & $13.36 \pm 0.39$ & 25.14 & 2.83 \\
\hline \multirow{2}{*}{$\begin{array}{l}\text { Potassium } \\
\text { silicates }\end{array}$} & Supper-gekal & $2.15 \pm 0.11$ & $9.65 \pm 0.26$ & $1.75 \pm 0.14$ & $13.55 \pm 0.28$ & 36.05 & 3.73 \\
\hline & Salymia (65010) & $2.20 \pm 0.16$ & $7.30 \pm 0.30$ & $2.65 \pm 0.15$ & $11.75 \pm 0.56$ & 18.48 & 2.53 \\
\hline \multirow{2}{*}{ Salicylic acid } & Supper-gekal & $2.19 \pm 0.13$ & $10.14 \pm 0.29$ & $2.10 \pm 0.14$ & $13.90 \pm 0.66$ & 37.28 & 3.68 \\
\hline & Salymia (65010) & $2.18 \pm 0.13$ & $7.36 \pm 0.31$ & $2.36 \pm 0.10$ & $11.55 \pm 0.54$ & 25.91 & 3.52 \\
\hline \multirow{2}{*}{$\begin{array}{l}\text { Methyl } \\
\text { jasmonate }\end{array}$} & Supper-gekal & $1.58 \pm 0.14$ & $9.89 \pm 0.31$ & $1.89 \pm 0.15$ & $13.37 \pm 0.38$ & 35.79 & 3.62 \\
\hline & Salymia (65010) & $1.89 \pm 0.11$ & $9.58 \pm 0.41$ & $2.16 \pm 0.12$ & $13.63 \pm 0.49$ & 28.16 & 2.94 \\
\hline \multirow{2}{*}{ Control } & Supper-gekal & $1.52 \pm 0.11$ & $12.35 \pm 0.37$ & $1.39 \pm 0.10$ & $15.26 \pm 0.36$ & 60.74 & 4.92 \\
\hline & Salymia (65010) & $1.83 \pm 0.10$ & $10.56 \pm 0.28$ & $1.74 \pm 0.14$ & $14.13 \pm 0.28$ & 47.65 & 4.50 \\
\hline
\end{tabular}

Table 3. Effect of two tomato hybrid on the of Tetranychus urticae life table parameters at $27 \pm 3^{\circ} \mathrm{C}$

\begin{tabular}{|c|c|c|c|c|c|c|c|}
\hline \multirow{2}{*}{ Treatments } & \multirow{2}{*}{ Tomato hybrids } & \multicolumn{6}{|c|}{ parameters } \\
\hline & & $\left(\mathrm{R}_{\mathrm{o}}\right)$ & $\left(\mathrm{r}_{\mathrm{m}}\right)$ & $(\lambda)$ & $(\mathrm{T})$ & (DT) & Sex ratio (female/total) \\
\hline \multirow{2}{*}{$\begin{array}{c}\text { Potassium } \\
\text { humates }\end{array}$} & Supper-gekal & 22.96 & 0.194 & 1.215 & 16.11 & 3.57 & 75.86 \\
\hline & Salymia (65010) & 19.10 & 0.162 & 1.176 & 18.15 & 4.28 & 76.00 \\
\hline \multirow{2}{*}{$\begin{array}{l}\text { Potassium } \\
\text { silicates }\end{array}$} & Supper-gekal & 24.87 & 0.208 & 1.231 & 15.45 & 3.33 & 69.00 \\
\hline & Salymia (65010) & 13.38 & 0.157 & 1.170 & 16.52 & 4.41 & 72.41 \\
\hline \multirow{2}{*}{$\begin{array}{l}\text { Salicylic } \\
\text { acid }\end{array}$} & Supper-gekal & 27.20 & 0.187 & 1.206 & 17.64 & 3.71 & 72.41 \\
\hline & Salymia (65010) & 19.65 & 0.168 & 1.183 & 17.72 & 4.13 & 82.00 \\
\hline \multirow{2}{*}{$\begin{array}{c}\text { Methyl } \\
\text { jasmonate }\end{array}$} & Supper-gekal & 23.45 & 0.199 & 1.221 & 15.82 & 3.48 & 65.52 \\
\hline & Salymia (65010) & 18.45 & 0.170 & 1.186 & 17.10 & 4.08 & 65.52 \\
\hline \multirow{2}{*}{ Control } & Supper-gekal & 48.17 & 0.236 & 1.266 & 16.41 & 2.94 & 79.31 \\
\hline & Salymia (65010) & 37.72 & 0.228 & 1.256 & 15.93 & 3.04 & 79.31 \\
\hline
\end{tabular}

$(\mathrm{T})=$ Generation time in days

$\left(r_{m}\right)=$ Intrinsic rate of natural increase per day
$\left(\mathrm{R}_{\mathrm{o}}\right)=$ Net reproductive rate.

$(\lambda)=$ Finite rate of increase per day. 
averaged 48.17 and 37.72 females/female /day respectively. Also, the intrinsic rate of natural increase $\left(\mathrm{r}_{\mathrm{m}}\right)$ showed similar trend.

\section{Histological characteristics of tomato leaves}

Data in table (4) and Fig. (1) showed that the compounds (Potassium humates, Potassium silicates, Salicylic acid and Methyl jasmonate) used in resistance enhancement in tomato plants affected the thickness $\mu \mathrm{m}$ of epidermis and parenchyma cells of tomato leaves, where it increased for untreated tomato plants (control). One of the most important factors that may explain the differences for the duration of developmental stage as well as adult female longevity, fecundity and the values of life table parameters of $T$. urticae is the thickness $\mu \mathrm{m}$ of epidermis and parenchyma cells may be due to the influence on feeding the red spider mite, T. urticae on the contents of cells. (Park and Lee 2002) stated that, adult $T$. urticae could feed through the spongy parenchyma and part of the palisade parenchyma of the leaf, while immatures $T$. urticae could feed only through the sponge parenchyma. $T$. urticae punctured individual epidermal cells and consumed the contents of the mesophyll cells. Also, (Jeppson, et al., 1975) stated that, the latter applies to spider mites (Tetranychus ssp.), the adults use stylets of c. $150 \mu \mathrm{m}$ long for lacerate-and flush feeding on mesophyll cells, predominantly parenchyma, of which it can empty up to $18-22$ cells per minute.

The transmission electron micrograph in Fig. (2) showed the differences of components in sponge and palisade parenchyma cells (pc-cellular wall, clchloroplasts, sp-intercellular space and sg- numerous starch grains) between the two tomato hybrids treated with the compounds (Potassium humates, Potassium silicates, Salicylic acid and Methyl jasmonate) and untreated tomato plants. The number of numerous starch grains per cell decreased in treated tomato plants compared with untreated ones (control), on the contrary observed chloroplasts per cell increased with treated tomato plants than untreated ones. Also, the number of numerous starch grains per cell in Suppergekal tomato hybrid was higher than Salymia tomato hybrid.

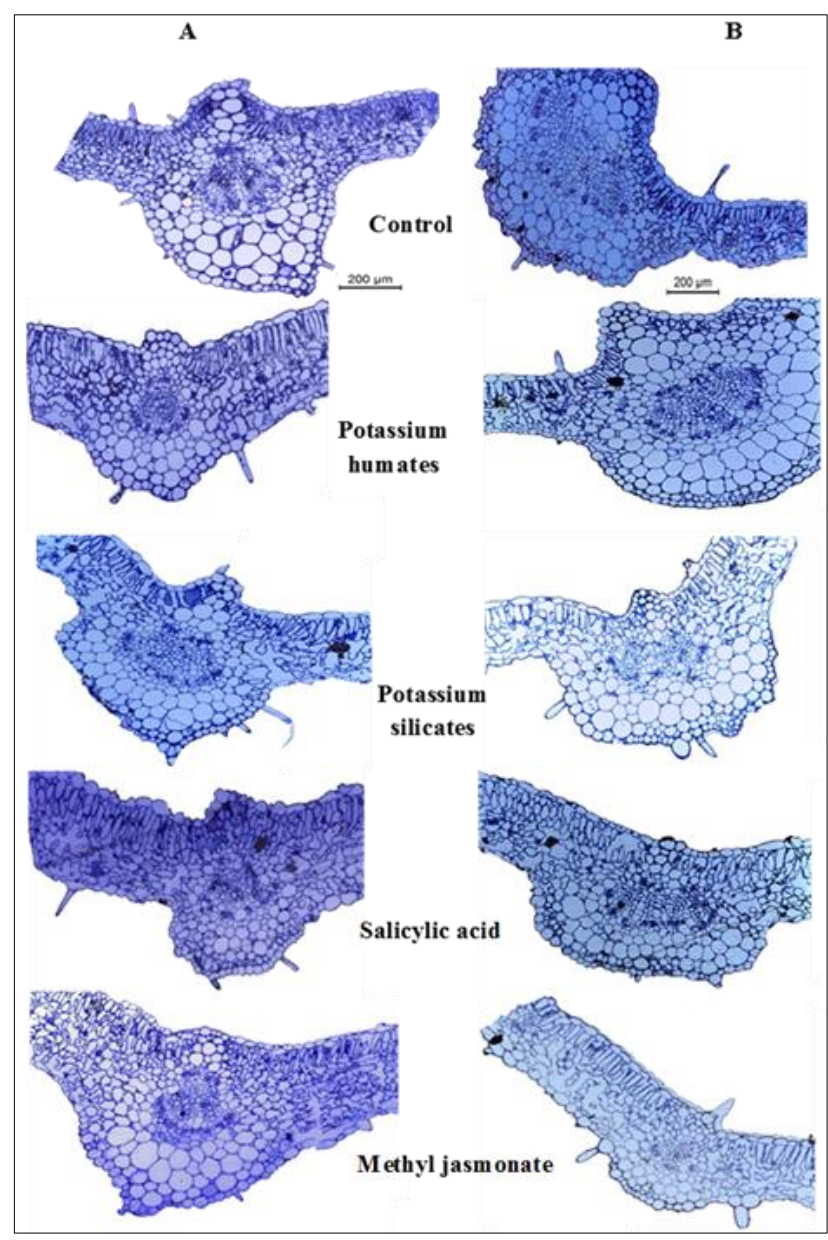

Fig. (1): Light micrograph cross section of tomato leaf across midrib showing upper epidermis, palisade parenchyma, spongy parenchyma and lower epidermis in leaflet of two tomato hybrids $(\mathrm{A}=$ Salymia and $\mathrm{B}=$ Supper-gekal $)$.

Table 4. Measurements of some histological characters in transverse sections of tomato leaves

\begin{tabular}{lccccc}
\hline \multirow{2}{*}{ Treatments } & Tomato hybrids & $\begin{array}{c}\text { Lower } \\
\text { epidermis }\end{array}$ & $\begin{array}{c}\text { Spongy thickness } \mu \mathrm{m} \pm \text { SE } \\
\text { parenchyma }\end{array}$ & $\begin{array}{c}\text { palisade } \\
\text { parenchyma }\end{array}$ & $\begin{array}{c}\text { Upper } \\
\text { epidermis }\end{array}$ \\
\cline { 2 - 5 } Potassium humates & Supper-gekal & $21.50 \pm 1.22$ & $86.58 \pm 4.43$ & $69.82 \pm 2.67$ & $26.50 \pm 2.00$ \\
\hline \multirow{2}{*}{ Potassium silicates } & Salymia (65010) & $33.36 \pm 2.11$ & $140.81 \pm 4.30$ & $118.47 \pm 3.40$ & $37.27 \pm 2.58$ \\
\hline \multirow{2}{*}{ Salicylic acid } & Supper-gekal & $26.90 \pm 2.02$ & $86.07 \pm 2.49$ & $68.45 \pm 1.58$ & $26.02 \pm 2.86$ \\
\cline { 2 - 6 } & Salymia (65010) & $30.36 \pm 2.28$ & $134.70 \pm 3.48$ & $117.45 \pm 2.99$ & $34.66 \pm 2.90$ \\
\hline \multirow{2}{*}{ Methyl jasmonate } & Supper-gekal & $25.38 \pm 2.31$ & $97.08 \pm 3.88$ & $73.90 \pm 2.56$ & $31.40 \pm 2.05$ \\
\hline \multirow{2}{*}{ Control } & Salymia (65010) & $29.14 \pm 1.65$ & $132.96 \pm 3.43$ & $112.98 \pm 2.63$ & $34.54 \pm 2.45$ \\
\cline { 2 - 6 } & Supper-gekal & $28.26 \pm 2.60$ & $88.40 \pm 2.30$ & $70.92 \pm 3.28$ & $28.96 \pm 2.68$ \\
\hline
\end{tabular}




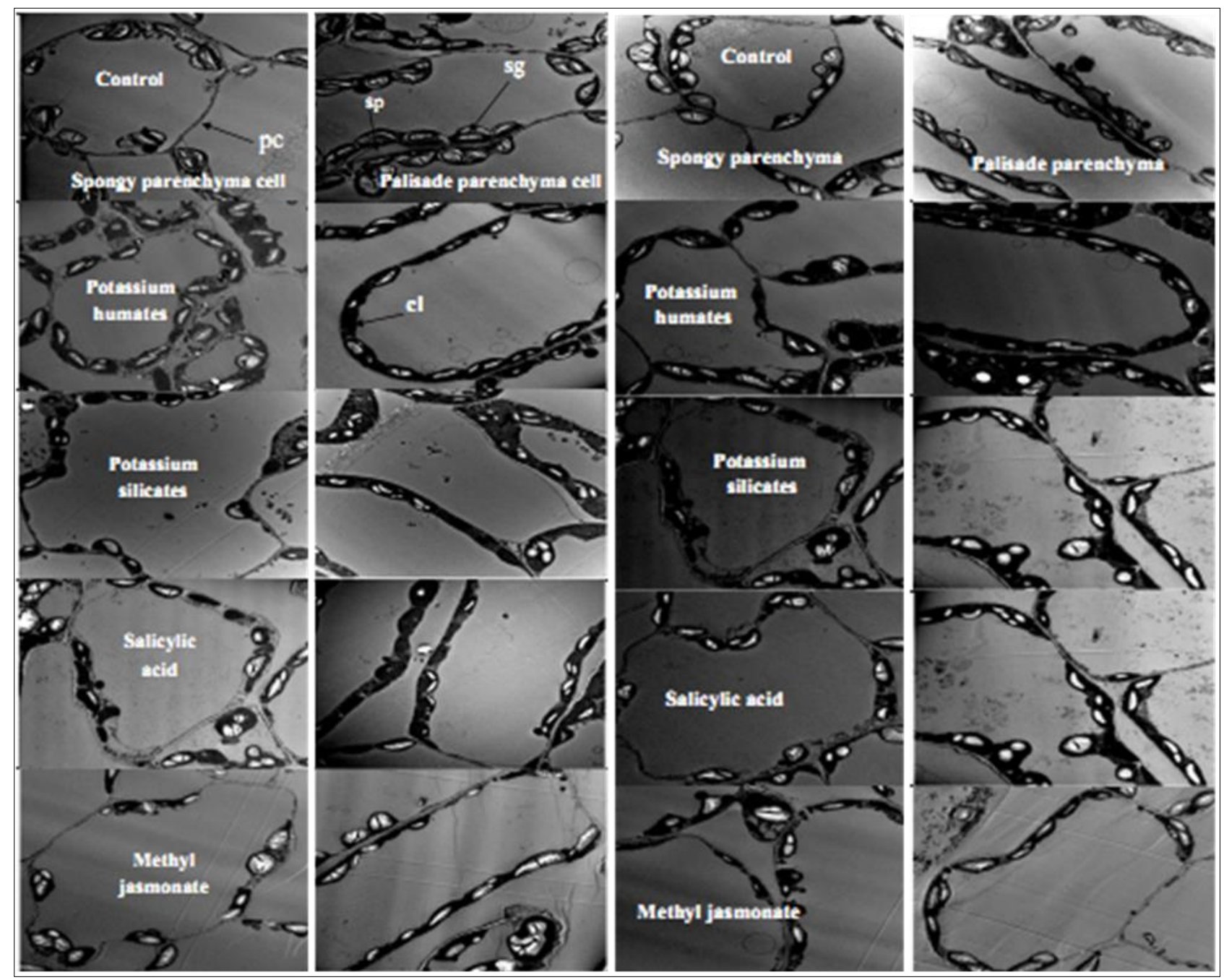

Fig. (2): Transmission electron microscopy used to investigate the differences of leaf parenchyma cells after resistance enhancement for supper-gekal tomato hybrid by potassium humates, potassium silicates, salicylic acid and methyl jasmonate compared with control.

Differences in the red spider mite, T. urticae fitness are influenced by tomato plant leaves morphological, histological and phytochemical components, as well as plant defense mechanisms. (Ali, et al., 2015) stated that, the susceptibility of five tomato hybrids Supper-gekal, F1Gs-12, El-basha 1077, Marwa and Salymia (65010) to infestation with T. urticae was affected by plant leaf morphological, histological structure and chemical characteristics. Trichomes, foliar glands, and epidermis-cuticle strata thickness are morpho-anatomical features that can constitute physical barriers to tetranychid feeding. These features are also correlated to a negative incidence in the development and reproduction of $T$. urticae (Bailey, et al., 1978). Differences in phytophagous arthropod responses to host plant quality also depends on quantity and nature of primary and secondary metabolites (van den Boom, et al., 2003). The shape of epidermal cells, as well as glandular and non-glandular trichomes, epidermis \& parenchyma thickness and chemical content from secondary compounds play an imperative role in tomato plant resistance against $T$. urticae, (Ali, et al., 2015 and Afifi, et al., 2015). Trichome density negatively affects the ovipositional behavior, feeding and larval nutrition of insect pests, (Handley, et al., 2005).

These variations determined on life table parameters of $T$. urticae might be due to leaf chemical contents, and its leaf texture. (Afifi, et al., 2015) mentioned that, the foliar application of Methyl jasmonate, Salicylic acid, potassium humates and Potassium silicate enhanced resistance in tomato plants against the red spider mite, Tetranychus urticae Koch by enhancing the concentrations of essential oil components (Caryophyllene, Humulene, $\beta$-phellandrene, d-Limonene, cis- $\alpha$ Copaene-8-ol, $\beta$-Spathulenol, Eugenol, 8-Cedren-13ol, Spathulenol, Geraniol, Humulene epoxide II, Caryophyllene Oxide, Delta-elemene, Linalool, $\beta$ Elemene and Methyl salicylate) and enhancing activity of defense enzymes such as Catalase (CAT), Peroxidases (POD), Polyphenol oxidase (PPO), 
Phenylalanine ammonia lyase (PAL, $\beta$-glycosidase and inhibition (\%) of the Proteinase inhibitors (PIs). In addition, it increased the densities of glandular and non-glandular trichomes.

These compounds (Potassium humates, Potassium silicates, Salicylic acid and Methyl jasmonate) used in resistance enhancement in tomato plants are significantly related to oviposition and development rates of $T$. urticae and playing an important role in the direct defence to the mite.

\section{REFERENCES}

Abou-Setta, M. M.; Sorrell, R.W. and Childers, C. C. 1986. Life-48, a BASIC computer program to calculate life table parameters for an insect or mite species. Fla. Entomol., 69 (4): 690: 697.

Afifi, A. M., Ali, F. S.; Shalaby, E. A.; El-Saiedy, E. M. A. and Ahmed, M. M. 2015."Enhancement of Resistance in Tomato Plants Using Different Compounds against the Two-spotted Spider Mites Tetranychus urticae Koch", Research Journal of Environmental Sciences, vol. 9, issue 3: 119-136.

Ali, F. S.; Afifi, A. M.; El-Saiedy, E. M. A. and Ahmed, M. M. 2013."Biology, Life tables parameters of Tetranychus urticae Koch and two phytoseiidae predatory mites on two watermelon Cultivars", Acarines, vol. 7, issue 1: 25-30.

Ali, F. S.; Afifi, A. M.; El-Saiedy; E. M. A. and Ahmed, M. M. 2015"Effect of Phytochemical Components, Morphological and Histological Leaf Structure of Five Tomato Hybrids on Tetranychus urticae Koch Infestation.", Acarines, vol. 9, issue 1: 23-30.

Bailey, J.; Furr, R.; Hanny, B. and Meredith, W. 1978. Field populations of two-spotted spider mites on sixteen genotypes at Stoneville. Journal of Economic Entomology, 71: 911-912.

Birch, L.C. 1948. The intrinsic rate of natural increase of an insect population. J. Arum. Ecol., 17: 15-26.

Bozzola, J.J. and Russell, L.D. 1999. Electron Microscopy, Second Edition. Sudbury, MA: Jones and Bartlett Publishers.

DePonti, O. 1985. Host plant resistance and its manipulation through plant breeding. Spider mites: their biology, natural enemies and control, vol 1A. (ed. Helle, W. \& Sabelis M.W.), p. 395403. Elsevier Science Publishers B.V. Amsterdam.

Golizadeh, A.; Jafari-Behi, V.; Razmjou, J.; Naseri, B. and Hassanpour, M. 2016. Population growth parameters of rose aphid, Macrosiphum rosae (Hemiptera: Aphididae) on different rose cultivars. Neotropical Entomology, 46(1): 100106.

Handley, R.; Ekbom, B. and Ågren, J. 2005. Variation in trichome density and resistance against a specialist insect herbivore in natural populations of Arabidopsis thaliana. Ecol. Entomol. 30: 284292

Jeppson, L. R.; Keifer, H. H. and Baker, E.W. 1975. Injurious Tetranychid mites. In: Jeppson LR, Keifer HH, Baker EW, eds. Mites injurious to economic plants. Berkeley, CA, USA: University of California Press, 127-252.

Park, Y.-L. and Lee, J.-H. 2002. Leaf Cell and Tissue Damage of Cucumber Caused by Two spotted Spider Mite (Acari: Tetranychidae). J. Econ. Entomol., 95(5): 952-957.

Shivaji, R.; Camas, A.; Ankala, A.; Engelberth, J. and Tumlinson, J.H. 2010. Plants on constant alert: Elevated levels of jasmonic acid and jasmonate-induced transcripts in caterpillarresistant maize. J. Chem. Ecol., 36: 179-191.

van den Boom, E.M.; Van Beek, T.A.; and Dicke, M. 2003. Differences among plant species in acceptance by the spider mite Tetranychus urticae Koch. Journal of Applied Entomology, 127: 177183.

Vásquez, C.; Pérez, M.; Dávila, M.; Mangui, J. and Telenchana; N. 2018. Biological parameters of Tetranychus urticae Koch (Acari: Tetranychidae) on strawberry cultivars in Ecuador. Revista Chilena de Entomología, 44 (3):271-278.

Verhage, A., S.C. van Wees and C.M. Pieterse, 2010. Plant immunity: It's the hormones talking, but what do they say? Plant Physiol., 154: 536-540.

War, A.R.; Paulraj, M.G.; War, M.Y. and Ignacimuthu, S. 2011. Jasmonic acid-mediatedinduced resistance in groundnut (Arachis hypogaea L.) against Helicoverpa armigera (Hubner) (Lepidoptera: Noctuidae). J. Plant Growth Regul., 30: 512-523. 